\author{
Harold Walter KROTO ${ }^{1}$, Maria ZIELIŃSKA ${ }^{2}$, Małgorzata RAJFUR ${ }^{2}$ \\ and Maria WACŁAWEK ${ }^{2}$
}

\title{
THE CLIMATE CHANGE CRISIS? ${ }^{3}$
}

\author{
KRYZYS KLIMATYCZNY?
}

\begin{abstract}
A necessary (though probably not sufficient) condition for creativity in the sciences and the arts to flourish is a liberal/democratic socio-political environment. In Europe this was manifested in the Enlightenment as Galileo, Copernicus and others laid the foundations for the evidence-based natural philosophy which signaled the birth of "The Enlightenment". The importance of intellectual and personal freedom for humanitarian advance is clearly manifested in the exponential success of the sciences in conquering many humanitarian problems from starvation and disease to the more obvious technologies that make modern life relatively pleasant for many especially in the developed world. On the down side however has been the reckless thirst of a plethora of governments to exploit the vast powers of the sciences to construct ever more powerful destructive weapons. Since then, the great thinkers from Kant to Russell, scientists from Einstein to Feynman and writers from Whitman to Shaw have repeatedly pointed to the importance of the doubt-based philosophy that is the crucial antidote to the stultifying effect of dogmas of all kinds. Indeed it is only doubt that leaves the road open for all advances in human endeavour. In the $21^{\text {st }}$ Century we have reached a watershed in that the human race now confronts a set of crises significantly more serious than any previously. These threats can only be overcome by an open minded liberal education of the next generation of young people. Before the name "Science" was coined it had another name, "Natural Philosophy" which more adequately describes its primary place in the spectrum of human culture. More important than any other aspect is the fact that Natural Philosophy is the only philosophical construct we have devised to determine Truth with any degree of reliability. As such it should be a primary ethical focus for the education of every child, student and citizen so at the very least they can decide whether what they are being told is actually true. This is also a strong intellectual basis for fostering creativity. For a truly humanitarian global society to evolve, equality of opportunity and personal freedom will be a necessary for all young people whatever their race, colour, nationality and most importantly sex. All technologies have the capacity to benefit society or to be detrimental and so as powerful new technical advances arise there is an onus on everyone to understand some important SET factors. As our modern world is so completely - and precariously - balanced on SET, an understanding of these disciplines by all in positions of responsibility is vital. Although wise decision-making may not be guaranteed by knowledge, common sense suggests that wisdom is an unlikely consequence of ignorance. Education is certainly a key factor and the Internet must be harnessed to improve matters. With the Vega Science Trust (www.vega.org.uk) an exciting new Global Educational Outreach for Science Engineering and Technology initiative GeoSet (www.geoset.info) and (www.geoset.fsu.edu) we are now working with other Universities to make outstanding educational material available on the Internet in any part of the world.
\end{abstract}

Keywords: climate, education, science, natural philosophy

\footnotetext{
${ }^{1}$ Department of Chemistry and Biochemistry, The Florida State University, Tallahassee Florida 32306-4390 USA

${ }^{2}$ Chair of Biotechnology and Molecular Biology, Opole University, ul. kard. B. Kominka 6, 45-032 Opole, Poland, phone +48 7740160 42, email: maria.waclawek@o2.pl

${ }^{3}$ Paper prepared on the basis of Prof. Sir Harold Walter Kroto lecture delivered during the 24th annual Central European Conference ECOpole'15, Jarnołtówek 14.10.2015. Background image of the slides was taken from: https://www.youtube.com/watch?v=IQ18q6EuEBs
} 
Sustainability - perhaps the biggest problem that we face today. And it is, in fact, an educational issue. Let's think a little bit about possible technical solutions.

For one thing, there could be quite a number of these:

1. Splitting water into hydrogen and oxygen;

2. Efficient solar electricity production;

3. Genetic development of wheat that can fix its own nitrogen.

We can think of hundreds of possibilities and the scientific community is working pretty hard to solve many of these.

However, we need to think further and more deeply, educationwise and think about the Sustainability Quotient, which I call PSQ (Positive Sustainability Quotient) ${ }^{4}$ and NSQ (Negative Sustainability Quotient) ${ }^{4,5}$

\begin{tabular}{|c|c|}
\hline & NSQ \\
\hline Refrigerators & -3 \\
\hline Aeroplanes & -3 \\
\hline Central Heating & -3 \\
\hline Cars & -4 \\
\hline Computers & -5 \\
\hline SUV's & -6 \\
\hline Air Conditioning & -7 \\
\hline Trucking & -10 \\
\hline
\end{tabular}

These are massive drains on the sustainability of the planet and we need to change that attitude very carefully, make people aware of what problems we may be facing in the future.

4 https://wwwtimeshighereducation.com/news/hamy-kroto/178673.article

5 that indicate on a scale from 10 to -10 
In fact, think of some other aspects. Local yogurt $(+3)$ and foreign yogurt $(-6)$. How did the foreign yogurt get to where it is being sold?

It came on a truck or ship or train - these are issues that are really quite serious in the future and its economic impact, as well.

I'll make only one exception and it is for Mozzarella di Bufala. The only place where they make a descent mozzarella is in Italy.

\section{SAVING THE PLANET}

Saving the planet is a global citizenship problem - we can not do it alone. Everybody on the planet must actually lend a hand to do this. It is an educational issue. In fact, a global educational issue.

There need to be a new attitude of children, a reverence for not only the Rainforests and trees, but also for wild animals - they must love them as much as they do their pets. 
And it goes deeper than that - we must set a good example as parents, we must recognize that "this fish is actually still alive". Imagine the squeal of a kitten hooked in the mouth and swung around the room!

Fish can not squeal, they have no vocal chord, but they re in pain - we know that from neurological studies.
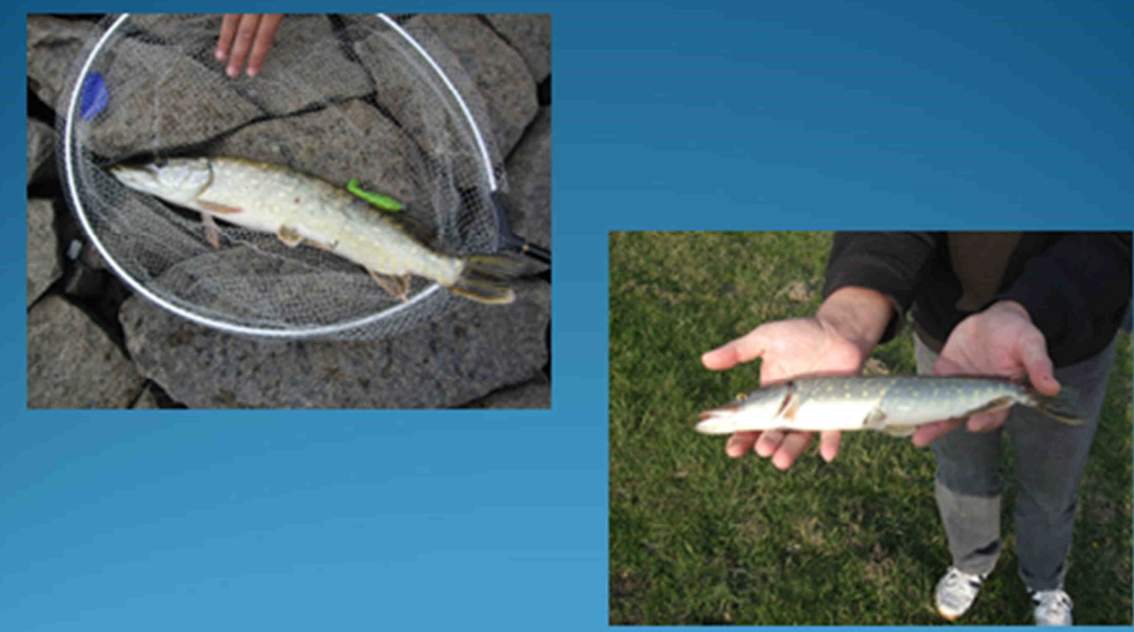

Do little children will be so happy if the fish that they re holding could squeal? I am not so sure. 
Father and son bonding. Is this a good example for our children?

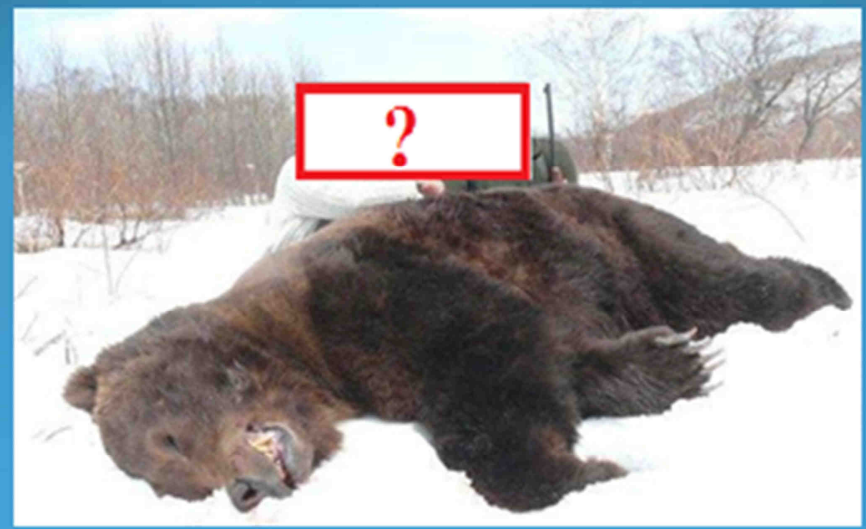

What sort of pleasure have they got from that?

There is another way to bring up our children.

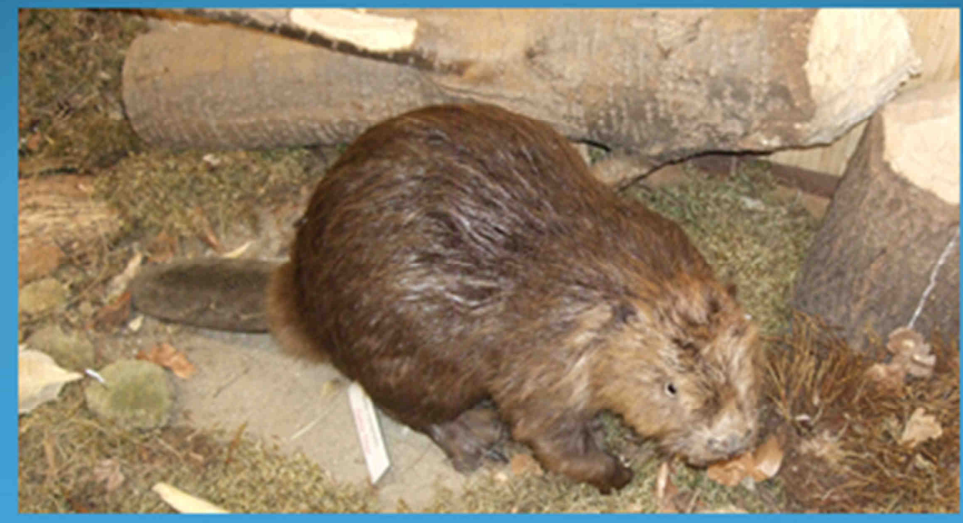

In fact, these animals were shot, but shot with a camera. 


\section{THE VALUE OF SCIENCE TO SOCIETY}

The value of science to society is not well understood. There are negative issues involving science and accidents do happen. However, in general the worst issues are because society makes unwise decisions on how scientific advances should be used in, for instance, armed conflicts, the wars that are going on right now on our planet.

In general I think most people would agree that by-and-large science, engineering and technology have provided great benefits to society.

\section{Let's give some examples:}

1. Anaesthetics - imagine the horror of past of legs being amputated without anaesthetics, women had their breasts surgeries without anaesthetics; there can be no more humanitarian contribution than the gift of anaesthetics from chemistry to society

2. Penicillin - a small molecule, a real miracle, saved people from blood poisoning in 1942 in 3 weeks (a year earlier those people may have died); we need young people

to realise that evolution is a fact and the bacteria are evolving with immunity to antibiotics. We need brilliant young kids who understand evolution to take up science and actually try to solve this problem in the future. 


\section{Let's give some examples:}

What it would be like without chemistry? All of the other scientists, such as physicists, biologists, engineers they say the very same thing - without chemistry life would be totally different.

\section{SCIENCE - WHAT IS IT?}

People do not fully appreciate science. There are several aspects that are really important to recognize the differences between them:

1. The body of knowledge and understanding of the way the physical and natural world work;

2. The application of that knowledge - technology;

3. The numerous ways in which this knowledge was actually discovered - scientific method. 
All of those however important they are, are not so important as something else. Before science became so useful it had another name

- Natural Philosophy.

In the perception of most people the incredible value of science to society has obscured the intrinsic philosophical nature of Natural Philosophy and its primary position in the spectrum of human intellectual achievement.

By far, the most important aspects is that Natural Philosophy is the only philosophical construct we have devised to determine truth with any degree of reliability.

And the Ethical Purpose of Education must involve the teaching of our young people how they can decide what they are being told is true.

Thus, the teaching of skeptical, evidence-based assessment of all claims without exception is fundamentally an intellectual integrity issue.

Without evidence, anything qoes! 


\section{The Royal Society}

Their first motto was "Quantum nescimus" - "What a lot we do not know" and it's still the same today as it was in 1660. We know very little at the present time. We are continually learning. However, they chose another one - „Nullius in verba" - "Take nobody 's word for it". I actually like this one better.

\section{There are 3 senses:}

1. Common sense - it tells us, that the Sun circles the Earth;

2. Uncommon sense - it tells us that the Earth is actually turning on its axis and this made it look as though the Sun was going round Us. How many of you know the evidence for this? Usually not many people put their hand up, sometimes none. In fact, how much else have you accepted without evidence? 


\section{There are 3 senses:}

We learn that we must be careful, very careful, question everything, assess all claims on the basis of evidence. It may take millennia to overcome the power of dogma based authority. In case of Galileo - 359 years; Margherita Hack said "Better late than never".

3. Common nonsense - now! More than it ever was before.

\section{CLIMATE CHANGE}

Climate change is a good example. We must examine the evidence of climate change:

1. Is there more or less rainfall in general around the world?

2. Is the average temperature rising?

3 . Are more glaciers receding than advancing?

4. Is the sea level rising in general?

5. Are animals moving from their natural habitats?

6 . Is the amount of $\mathrm{CO}_{2}$ in the atmosphere increasing?

7. Has there been any increase or decrease in hurricanes?

8. Is there more or less ice in the Arctic and Antarctic? 


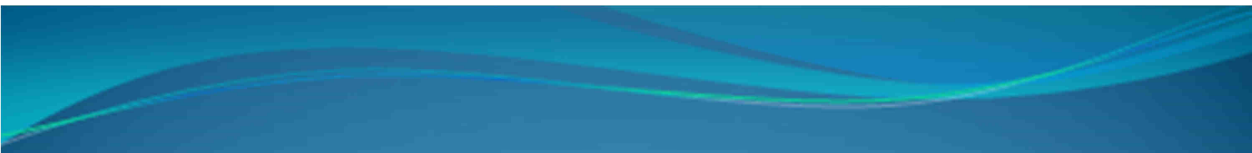

We must look at the indicators and do the assessment ourselves, of what is going on. Take no ones word for it.

Look on the evidence yourself and make a decision for yourself. That's science.

That is what we must do and that is we must teach everybody on the planet - not to accept what best of interest tells them.

Very few people have really important valuable mathematical ability. As an example, many nurses have poor mathematical skills. They do not know where to put the decimal point. Patients might get 10 times more or 10 times less medication than they should.

In 1999 between 45,000 and 98,000 Americans died due to medical errors, many due to the calculation mistakes. 

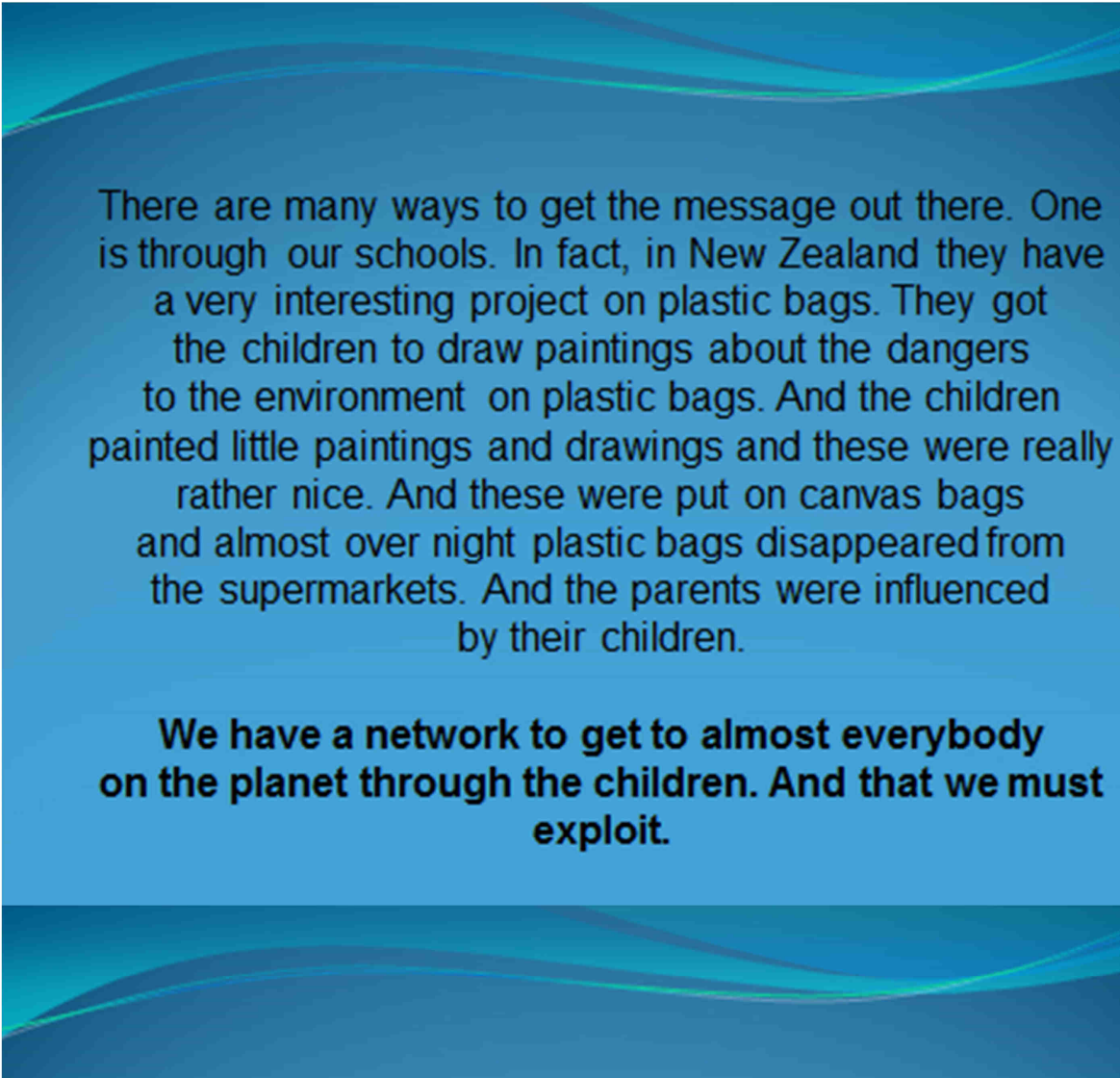

Kids workshops all over the world, from Japan to Santa

Barbara (California), Mexico, Malaysia, Iceland and by the internet across the whole of Australia and UK. The internet is our new weapon in this exercise. I set up the VEGA Science trust some years ago to make programs

for television and in fact, it was the first revolution in education and it was a printing press. The second revolution is the internet.

Vega has pioneered a new concept in TV debate. Participants should actually know something. 


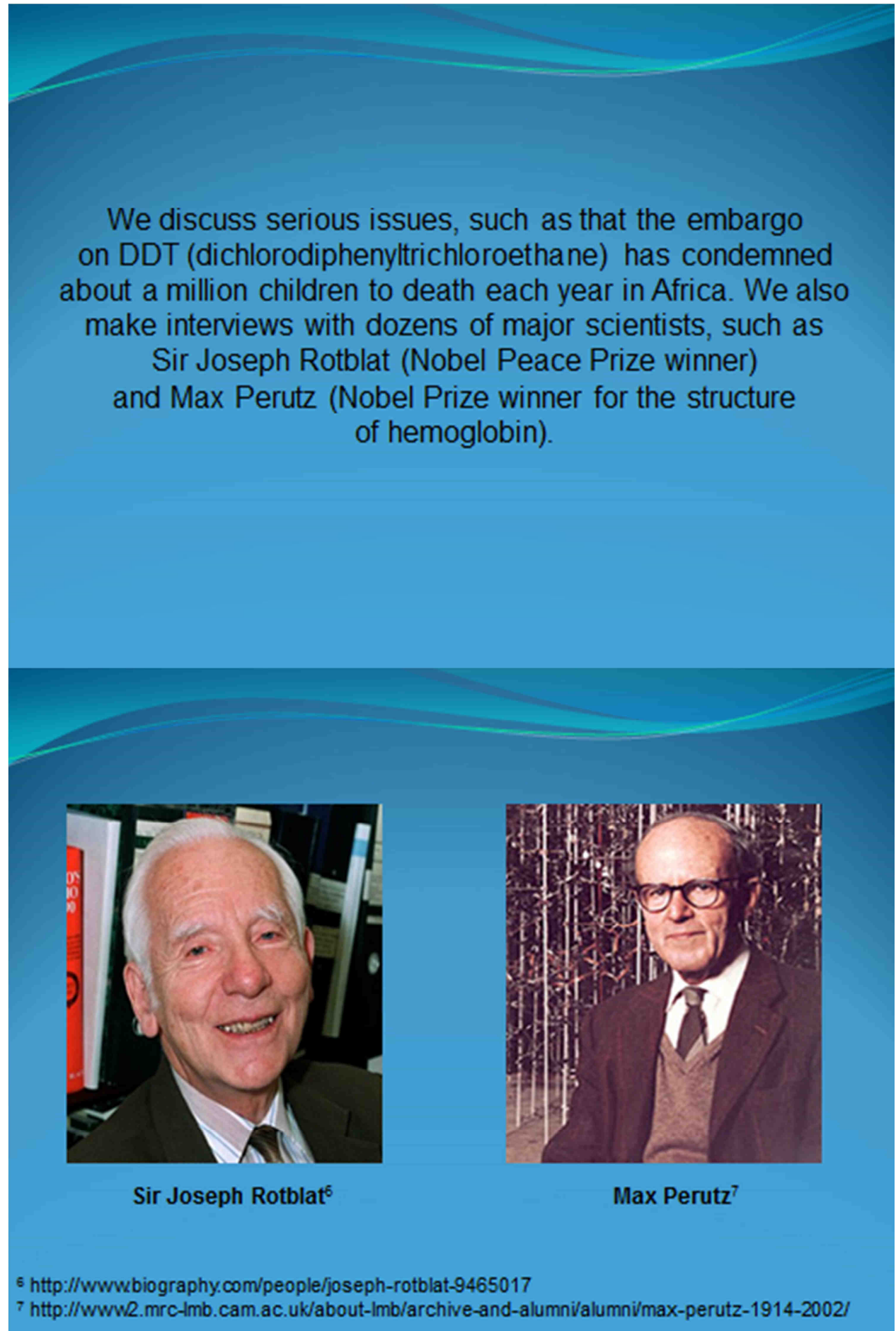




\section{THE ENCYCLOPEDIAS}

How many of you have actually looked in the new encyclopedia? This is a revolution. Now we have a new weapon and it is a powerful one - the GooYouWiki World (GYW-W).

\section{Only internet.}

We use a capture station technology - the way I am coming to you now. We have a video of the speaker or teacher together with the data file. It could be on a blackboard and it could be downloadable. We can make this material available to every teacher on the planet. It is the future of broadcasting.

Here are some websites you can use:

$$
\begin{aligned}
& \text { www.geoset.info } \\
& \text { www.geoset.fsu.edu }
\end{aligned}
$$




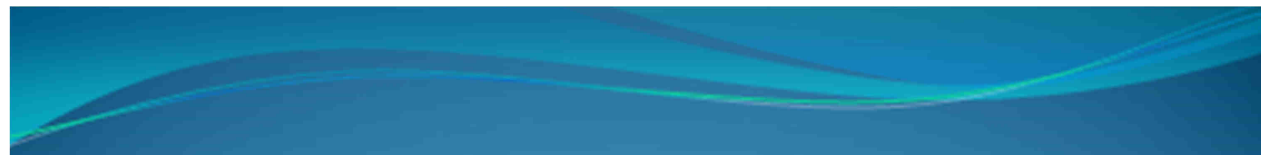

Kids, undergraduates and graduates are fantastic at making presentations because they have something special, they have enthusiasm for the project they are involved with.

We have actually revolutionized the resume. Instead of the resume being a pile of paper, we are putting our students right on the top of that pile so the people who are assessing them know much more about them.

\section{This works and is the future for students getting} scholarships and jobs.

\section{THE DUNG BEETLE}

This is my favourite animal now. And you know what he is sitting on - yes, it is a ball of elephant excrement.

It is actually a sustainability animal - it is recycling this excrement. But let's look at our world. What is the excrement that we have produced? There is a field in England with a 140,000 refrigerators just dumped there. We have to recycle our own excrement.

We have to develop our own robots to do this and make sure that we have a sustainable world. 


\section{CONCLUSIONS}

In the $21^{\text {st }}$ Century we have reached a watershed in that the human race now confronts a set of crises significantly more serious than any previously. These threats can only be overcome by an open minded liberal education of the next generation of young people.

For a truly humanitarian global society to evolve, equality of opportunity and personal freedom will be necessary for all young people whatever their race, colour, nationality and gender.

\section{CONCLUSIONS}

Although wise decision-making may not be guaranteed by knowledge, common sense suggests that wisdom is an unlikely consequence of ignorance.

Education is certainly a key factor and the Internet must be harnessed to improve matters. 


\title{
KRYZYS KLIMATYCZNY?
}

\author{
${ }^{1}$ Department of Chemistry and Biochemistry, The Florida State University, Tallahassee, Florida, USA \\ ${ }^{2}$ Samodzielna Katedra Biotechnologii i Biologii Molekularnej, Uniwersytet Opolski, Opole, Polska
}

\begin{abstract}
Abstrakt: Niezbędnym (choć prawdopodobnie niewystarczającym) warunkiem zapewnienia kreatywności w zakresie nauki i sztuki jest rozwój liberalno-demokratycznego środowiska społeczno-politycznego. W Europie zależność ta widoczna była między końcem VII a początkiem XIX wieku, kiedy to Galileusz, Kopernik i inni tworzyli podstawy filozofii naturalnej, opartej na dowodach, co oznaczało początek „oświecenia”. Znaczenie wolności intelektualnej i osobistej dla rozwoju idei humanistycznych widać wyraźnie w sukcesach nauki w zwalczaniu wielu problemów ludzkości, począwszy od głodu i chorób, skończywszy na technologiach, które znacznie ułatwiają życie ludziom, szczególnie w krajach rozwiniętych. Zjawiskiem negatywnym jest dążenie wielu rządów do wykorzystywania mocy nauki w celu budowy coraz potężniejszych środków destrukcji. Od czasów oświecenia wielu wielkich myślicieli: od Kanta do Russela, naukowców: od Einsteina do Feynmana, i pisarzy: od Whitmana do Shawa, podkreślało wielokrotnie znaczenie filozofii opartej na wątpliwości, która stanowi istotne antidotum na porażające działanie wszelkiego rodzaju dogmatów. I rzeczywiście - jedynie wątpliwość otwiera drogę dla wszelkiego postępu w działalności człowieka. W XXI wieku osiągnęliśmy pewien próg rozwoju, a ludzkość stoi przed wieloma problemami, znacznie poważniejszymi niż te w przeszłości. Te problemy i zagrożenia można pokonać poprzez wdrażanie liberalnej, otwartej edukacji wśród kolejnej generacji młodych ludzi. Zanim powstał termin „,nauka”, stosowano określenie „filozofia naturalna”, które bardziej adekwatnie określa jej miejsce w spektrum kultury człowieka. Najważniejsze jest to, że filozofia naturalna jest jedyną koncepcją filozoficzną, która w jakimś stopniu może pomóc w dotarciu do prawdy. Jako taka, filozofia ta powinna stanowić podstawę etyczną edukacji każdego dziecka, studenta i obywatela, aby byli oni w stanie ocenić, czy treści im przekazywane są zgodne z prawdą. Stanowi to także mocną podstawę intelektualną dla wspierania kreatywności. Aby stworzyć rzeczywiście humanistyczne społeczeństwo globalne, konieczne jest zapewnienie możliwości i wolności osobistej wszystkim młodym ludziom bez względu na ich rasę, kolor, narodowość i, co najważniejsze, płeć. Każda technologia może być pożyteczna lub szkodliwa dla społeczeństwa; w związku z jej szybkim rozwojem wszyscy musimy rozumieć pewne najważniejsze kwestie dotyczące SET (nauka, inżynieria, technologia). Ponieważ nasz świat tak bardzo zależny jest od nauki, inżynierii i technologii, niezwykle istotne jest zrozumienie tych dyscyplin przez wszystkich, którzy zajmują istotne pozycje w społeczeństwie. Chociaż wiedza nie gwarantuje podejmowania mądrych decyzji, wydaje się jednak, że mądrość nie wynika z ignorancji. Edukacja jest elementem najważniejszym, a Internet należy wykorzystać do jej poprawy. Wraz z Vega Science Trust (www.vega.org.uk) nową, globalną inicjatywą edukacyjną w zakresie nauk ścisłych i technologii GeoSet (www.geoset.info i www.geoset.fsu.edu) współpracujemy aktualnie z innymi uniwersytetami, aby udostępnić w Internecie wartościowe materiały edukacyjne dla wszystkich zainteresowanych na całym świecie.
\end{abstract}

Słowa kluczowe: klimat, edukacja, nauki ścisłe, filozofia naturalna 